\title{
COMERSE LAS UÑAS DEL YO: LA ESCRITURA DIARÍSTICA Y AUTOBIOGRÁFICA DE LORENZO GARCÍA VEGA*
}

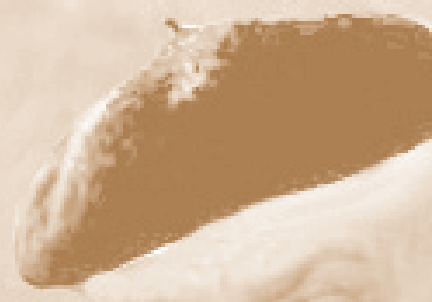

\author{
BITING THE NAILS OF THE SELF: DIARY AND \\ AUTOBIOGRAPHIC WRITING OF LORENZO GARCÍA VEGA
}

\section{JESÚS GÓMEZ-DE-TEJADA**}

\section{RESUMEN}

Lorenzo García Vega desarrolló una cuantiosa escritura autobiográfica, cuya impronta permea abundantemente el resto de géneros (poesía, narrativa y ensayo) que constituyen su producción. Este artículo focaliza especialmente la escritura diarística del escritor: tras presentar sus principales textos autorreferenciales y subrayar las recurrencias temáticas y estilísticas de estos, el estudio finaliza con el análisis de Rostros del reverso (1977) como diario literario (Luque Amo, 2016). En esta obra, García Vega da testimonio de los últimos años pasados en La Habana antes del triunfo de la Revolución cubana, el periodo de tránsito en Madrid como exiliado y, finalmente, la estada en Nueva York. La crónica personal cotidiana del periodo comprendido entre 1952 y 1975 constituye una experiencia transmigráfica (Mesa Gancedo, 2013) que construye un yo en conflicto continuo con la Revolución, el exilio y consigo mismo.

Palabras clave: Lorenzo García Vega, diario, autobiografía, literatura cubana, literatura hispanoamericana.

\section{ABSTRACT}

Lorenzo García Vega developed a substantial autobiographic writing, whose imprint permeates abundantly other genres (poetry, narration and essay) that make up his pro-

* Este trabajo se enmarca en el Proyecto FONDECYT Postdoctorado 2015 No 3150177 (CONICYT, Chile), que lleva por título "La isla y sus espejos: redes de la memoria cubana del siglo XXI", del que soy investigador responsable.

** Docente e investigador, IDESH. Universidad Autónoma de Chile, Santiago, Chile. Correo: jgomezdetejada4@gmail.com 
duction. This paper focuses mainly on the author's diary writing: after reflecting on his main auto-referential texts and highlighting the thematic and stylistic recurrences in them, the study is centred on the analysis of Rostros del reverso (1977) as a literary diary (Luque Amo, 2016). In this work, García Vega testifies about the last years spent in Havana before the triumph of the Cuban Revolution, the transition timeframe in Madrid as an exile and, finally, his stay in New York. The everyday personal chronicle, from 1952 to 1975, is a transmigraphic (Mesa Gancedo, 2013) experience that builds a self in continuous conflict with the Revolution, exile, and himself.

Keywords: Lorenzo García Vega, diary, autobiography, Cuban literature, Hispanic American literature.

Recibido: 18.04.17. Aceptado: 19.07.17.

\section{LA PULSIÓN DEL YO: DIARIOS, MEMORIAS Y AUTOBIOGRAFÍA}

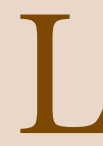

A ESCRITURA AUtORREFERENCial de Lorenzo García Vega (Jagüey Grande, Cuba, 1926 - Miami, EE.UU., 2012) está marcada por una trayectoria transatlántica motivada por el exilio. En 1968 el autor sale de Cuba con destino a Madrid, pero con la intención de obtener lo más rápidamente posible la visa que lo lleve a EE.UU. En 1970 llega a Nueva York y allí permanece hasta 1977. Entre 1977 y 1980 vive en Caracas, Venezuela. Finalmente, vuelve a EE.UU. y se radica en Miami hasta su muerte.

El signo autobiográfico está presente en la mayoría de sus textos en prosa y en verso, ya que, como asevera Arcos, "la memoria será uno de los componentes más fuertes -estructural y cosmovisivamente- de su poética" (Arcos, 2012, p. 19). La obra heterogénea, difícilmente clasificable, de García Vega se esfuerza por romper los límites genéricos y tiende a entrecruzar la poesía, la prosa de ficción, el texto ensayístico y el autobiográfico. Quizás el término zuihitsu, concepto que toma de la literatura clásica japonesa con el fin de referirse a su obra Vilis $(1998)^{1}$, sirva para aproximarse a la realidad de muchos de sus títulos, que quedarían descritos como "colección de frag-

\footnotetext{
${ }^{1}$ Rudd ha estudiado el potencial de este género japonés en la poesía estadounidense posmoderna. En su artículo afirma que "un zuihitsu puede consistir en una serie de ensayos y anécdotas desconectadas tanto como frases inconexas, fragmentos, ideas, palabras-imágenes, poemas, listas y piezas de conversaciones" (Rudd, 2011, pp. 42-43; mi traducción). Además cita a Donald Keene, que caracteriza el zuihitsu como "una colección 'de breves ensayos de temas aleatorios' en la que 'las observaciones y reflexiones del escritor son presentadas con gracia estilística' (Keene 1,9) [... y] añade que 'después de leer una serie de anécdotas e impresiones sin relación aparentemente, podemos, no obstante, sentir una gran sensación de intimidad con el escritor, tanto como si hubiéramos leído su diario o quizás una I novel en la que expusiera las alegrías y penas de su vida”" (Rudd, 2011, p. 43; mi traducción).
} 
mentos, anécdotas, anotaciones, observación de cosas curiosas, descripción de sentimientos y cosas por el estilo, todo ello sólo, por casualidad con relación entre sí” (en García Vega, 2005b, p. 52).

Más allá de esta hegemonía de lo memorístico en el conjunto de su producción, los libros más explícitamente autorreferenciales son Rostros del reverso (1977), Los años de Orígenes (1978) y El oficio de perder (2004). Esta condición se refuerza en Rostros del reverso por la estructura en forma de diario y en El oficio de perder a través del subtítulo de Memorias con que el autor lo designa. Por su parte, Los años de Orígenes, que ha sido definido como ensayo autobiográfico, no difiere de los otros dos títulos ni en lo estilístico ni en la fuerte presencia del yo, como él mismo manifiesta enfáticamente en una entrevista al afirmar que "no escribí un texto de historia literaria sobre un periodo de ella en que yo hubiera participado. Yo lo que escribí fue un testimonio de mi vida" (en Espinosa Domínguez, 2016, p. 99) 2 . De hecho, la escritura de cada uno de ellos evidencia una continuidad, simultaneidad y recurrencia innegables no solo en los recursos, sino también en múltiples rasgos temáticos y, parcialmente al menos, en el tiempo de la redacción. La pulsión autorreferencial persiste hasta el final de los días de García Vega. En las últimas páginas de El oficio de perder anuncia la existencia de un diario inédito titulado El cristal que se desdobla, y en una entrevista de 2008 asegura estar componiendo uno nuevo:

[E]spero poder publicar mi penúltimo diario, El cristal que se desdobla, si es que encuentro un editor. ¿A quién le va a interesar un diario de un hombre que se pasó diez años trabajando de bag boy en un supermercado de la Playa Albina. Y sigo con mi último diario, el que se publicará cuando ya yo esté en el cielo. Como ves, empecé en 1952, con los Rostros del reverso, y sigo inventándome (Arcos, 2008, s.p.) ${ }^{3}$.

Tal y como aparece en una reciente monografía sobre el autor, coordinada por Carlos Alberto Aguilera y titulada La Patria Albina (2016), ambos diarios han quedado sin publicar. Además de confirmar el título anunciado

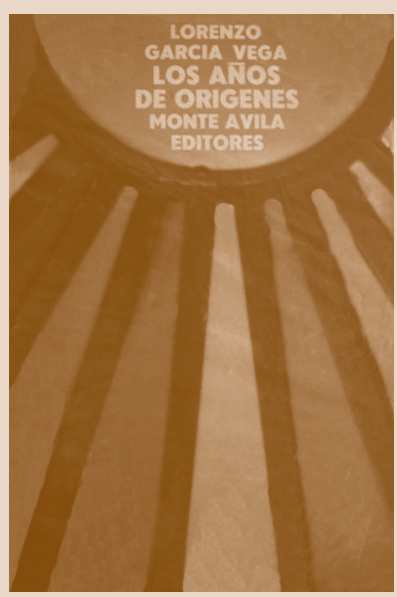

\footnotetext{
${ }^{2}$ La edición argentina de esta obra se subtitula así: Los años de Orígenes: ensayo autobiográfico (Buenos Aires: Bajo la luna, 2007).

${ }^{3}$ Mesa Gancedo, que cita esta entrevista, añade que "sus últimas obras tienen también ese carácter de diario sin fechas: el inédito Taller de desmontaje (parcialmente publicado en La Habana elegante 2007; en <http://www.habanaelegante.com/summer2007/angel.html>) o las prosas de Erogando trizas donde gotas de lo vario pinto (Huelva: La Palma, 2011). Sus manuscritos están en la universidad de Princeton (desde agosto de 2011) y probablemente haya allí más diarios, como los legajos titulados "Diarios de sueños" o "Cuadernos de bag-boy” (Gancedo, 2013: 1555).
} 
para el primero, Aguilera nos revela que el segundo iba a titularse Rabos de anti-nube (Aguilera, 2016, p. 189). A ellos, todavía hay que añadir el blog denominado La pata sobre el huevo, que comienza a publicar -comenta Margarita Pintado- "cuatro meses antes de morir" (Pintado, 2016, p. 33) en cuarenta y cuatro entradas entre principios de febrero y el 29 de abril de 2012, aunque los textos fueron escritos entre julio y septiembre de 2011. García Vega subtitula esta obra como "diario onírico" y la describe como "traducción del sueño" de esos días o, mejor, de esas noches (García Vega, 2011, s.p.).

En definitiva, esta continuidad del carácter autobiográfico de la escritura, o dicho de otra manera, la constante explicitación de sí mismo en sus textos literarios se condensa perfectamente en una frase -con visos de greguería- de García Vega: "Cuando no sé qué hacer me como las uñas del yo" (García Vega, 1977, p. 131). En este sentido, la afinidad de la personalidad y el estilo del autor de Rostros del reverso con la escritura diarística confirma las opiniones de Gusdorf y Lejeune en torno a la idea de que "la tarea de quien escribe un diario deviene en 'hábito', en una práctica continuada que es también una manera de vivir" (Hierro, 1999, p. 113).

Los años de Orígenes fue escrito durante su exilio en Nueva York a lo largo de los años setenta, mientras trabajaba como empleado en una oficina de seguros y, después, como portero de una tienda de la marca Gucci. Este título es un escrito autobiográfico donde García Vega analiza su controvertida relación con los otros intelectuales del grupo origenista y con su líder, Lezama Lima, en La Habana durante los años cuarenta y cincuenta. La polémica suscitada por esta publicación -aproximadamente un año después de la muerte de Lezama- resuena en los libros dedicados al estudio del origenismo ${ }^{4}$. La controversia en torno a la realidad y justicia de la visión dada por García Vega sobre los ceremoniales origenistas y el alcance de su poética le valió al autor el repudio de los miembros del grupo y de sus afines.

El oficio de perder se redactó en Miami al comienzo de la década del siglo XXI, cuando el autor se desempeñaba como bagboy -rellenando las bolsas de los clientes- en uno de los supermercados de la cadena Publix

\footnotetext{
${ }^{4}$ Por ejemplo, en Orígenes: la pobreza irradiante (La Habana, 1994), de Jorge Luis Arcos; El libro perdido de los origenistas (Sevilla, 2004), de José Antonio Ponte; Límites del origenismo (Madrid, 2005), de Duanel Díaz Infante; y Cuba and the New Origenism (Woodbridge, 2010), de James Buckwalter-Arias. Títulos a los que habría que añadir el monográfico dedicado por Arcos al autor de El oficio de perder titulado Kaleidoscopio: la poética de Lorenzo García Vega (Madrid, 2012), que fue contestado en el artículo "La persistencia de Orígenes” publicado por Duanel Díaz en la revista La Habana Elegante en 2013.
} 
para subsistir. Aquí García Vega evita volver a centrarse en el magisterio de Lezama, aunque no faltan las alusiones al autor de Paradiso (1966). En su lugar, focaliza el discurso en la infancia transcurrida en el pueblo natal, en la juventud vivida en La Habana y, finalmente, en la vejez como exiliado en Miami, ciudad que aparece de modo insistente como marco actual desde el que se escribe. El texto está pensado y creado desde una perspectiva cercana a la muerte, que ya no es más una realidad remota y abstracta, sino un horizonte real y próximo. Como indica Sergio Franco, se acepta ampliamente que este es un momento bueno para recordar y pensar en la infancia como el tiempo donde todo es posible, en oposición al tiempo de la escritura, cuando para el autor todo está llegando al final (Franco, 2012, p. 171).

García Vega explica en una entrevista con Cuba Soria que siente como inextricable su conversión en autor de autobiografía (en Cuba Soria, 2016, p. 110) y afirma que en la práctica del género "mi manera de inventarme mi pasado, se había transformado en un Laberinto" (en Cuba Soria, 2016, p. 112). La recurrencia a esta imagen mítica hace de cada página, cada frase y cada palabra un nuevo muro que impide la salida hacia un fructífero y nítido autoconocimiento, que imposibilita el hallazgo expresivo de un rostro incontestable. La transcripción de este laberinto aspira a materializarse como la radiografía del recorrido memorístico que de manera tediosa, trastabillante y agónica asedia cognitivamente el reverso de ese yo. Ante la falta de salida, la única opción es narrar el laberinto o como dice en su introducción a Los años de Orígenes, convertirse en un narrador Zen: "Sólo testificando que hubo un nudo, un obstáculo, el narrador logrará desarrollar lo que no puede desarrollar, ni necesita ser desarrollado" (García Vega, 1978, p. 11).

Las características que Toro señala para la meta-autobiografía (2007) y que estructuran El oficio de perder son reconocibles en gran medida en sus otros textos de carácter autobiográfico -Los años de Orígenes y Rostros del reverso-. Los rasgos definitorios del estilo del escritor más sobresalientes son: la falta de unidad o el distanciamiento entre el autor y el personaje autobiografiado; el desplazamiento de la vida del yo como tema central; la inestabilidad o la explícitamente baja fiabilidad del narrador que no ofrece verdades, sino posibilidades, tentativas y argumentaciones sobre el yo y la acción de testimoniar; la tensión de la escritura que recurrentemente se niega a sí misma en un ejercicio de redacción y borrado continuo; la fragmentariedad del texto y de la vida que se ofrece; la intertextualidad y el discurso metarreflexivo.

El propio autor cuestiona a menudo la obra como resultado de una 
expresión endogámica, autista, repetitiva y balbuciente. García Vega construye la palabra autobiográfica sobre la conciencia de la imposibilidad de edificar un laberinto testimonial. Desde esa certeza y según nos indica, las claves estilísticas del discurso se instalan paradójica y voluntariamente en la inmadurez (Witold Gombrowicz) y la inexpresividad (Clarice Lispector) de una voz que se repite y repite en busca de una forma estética del tedio. Esta propensión estilística hacia el hastío rechaza lo sentimental y anecdótico para focalizar lo objetivo de las cosas: "me obsede dar con el hacha para quedar en la seca estructura, en el hueso último", confiesa (en Cuba Soria, 2016, p. 116). La búsqueda de objetivación al narrar le lleva a dinamitar tenaz y meticulosamente la descripción de cualquier anécdota a través de una prosa (de)construida sobre el metalenguaje, la repetición, la yuxtaposición y, a veces, la agramaticalidad que permiten analizar El oficio de perder desde los presupuestos de la meta-autobiografía. En este sentido, asevera en Rostros del reverso:

Releo lo que anteriormente he escrito, y me vuelvo a preguntar si puede tener algún sentido para los demás el referir una circunstancia desde la imagen. Siempre he tendido a ésto [sic]: referir una circunstancia, criticar un texto literario, o describir una situación, desde mi centro, o sea, desde las imágenes que en ese momento me persiguen (García Vega, 1977, p. 106).

Lejeune al teorizar sobre la valoración y práctica del diario afirma la ambivalencia de este con respecto de la autobiografía, entre el mencionado carácter desestructurado y reiterativo del primero, y "la búsqueda de un significado" y "la creación de una forma" que ofrece la segunda (Lejeune, 2012, p. 151; mi traducción). Al igual que él, aunque sin las consideraciones negativas que Lejeune reconoce haber tenido hacia el diario como género, García Vega pasa alternativamente de la escritura diarística a la autobiográfica y de nuevo al diario. El repudio que expresa sobre su escritura -diarística o no- es parte de su estilo, de su personalidad, de su neurosis y de lo que llama su oficio de perder. Repudio que, no obstante, no le priva de escribir y publicar casi compulsivamente. Para Maurice Blanchot: "el Diario señala que quien escribe ya no es capaz de pertenecer al tiempo por la firmeza ordinaria de la acción, por la comunidad del trabajo, del oficio [...] pero [...] como sólo sabe escribir, escribe, al menos, a pedido de su historia cotidiana y de acuerdo con la preocupación de los días" (Blanchot, 2002, p. 25). De igual manera, García Vega explica que "siempre he acudido al Diario. Siem- 
pre estoy escribiendo un Diario. Antes que nada, para construirme. Para [...] inventarle una historia a mi vida" (Arcos, 2008, s.p.).

Los textos de carácter autobiográfico de García Vega se presentan como un discurso fragmentario, radicalmente opuesto a la vieja y tradicional concepción de la vida y de su relato como totalidad y univocidad. Los años de Orígenes, El oficio de perder y el diario los Rostros del reverso presentan una organicidad significativa. Por un lado, en la singularidad y persistencia del estilo. Por otro, en la reiteración de las obsesiones temáticas: la época de Orígenes, la vacuidad de la Cuba republicana y el desengaño revolucionario, la inanidad del exilio, la dificultad de la expresión literaria, el asedio a un yo fragmentario y huidizo a la memoria y a la escritura.

\section{EL DIARIO LITERARIO}

De los subgéneros concebidos como autobiográficos, es decir, aquellos donde la reflexión sobre el yo del autor y su contexto escrita en primera persona ocupa el foco principal, el diario es el que tradicionalmente menor presencia editorial y atención crítica ha tenido en España (Freixas, 1996, p. 6). Aún más restringida ha resultado esta producción si el foco de análisis se sitúa en el ámbito hispanoamericano (Mesa Gancedo, 2014, p. 193). En los últimos años, no obstante, se ha percibido un cambio significativo y se asiste a un "auténtico fervor por el género" en español (Gallego Cuiñas, Estrade \& Idmhand, 2016, p. 10).

A pesar de compartir la perspectiva autorreferencial, el diario presenta características diferenciales frente al resto de subgéneros autobiográficos (autobiografía, memorias, epistolario), si bien -señala Bou (1996, p. 122)en él se producen "con facilidad préstamos intragenéricos", que lo acercan al libro de viajes o a las memorias. Frente a la totalidad a la que aspira la autobiografía en su evocación del pasado, el diario, a partir de la llamada cláusula del calendario -apriorística limitación del contenido a la data que precede al texto en cada una de sus entradas-, se define por el carácter fragmentario, cotidiano y hodierno, además de por su perspectiva personal (Luque Amo, 2016, pp. 293-295). Según Picard, el "fragmentarismo, la incoherencia a nivel textual, su referencia a una situación vital concreta, lo abreviado de la información" son los rasgos identificadores del género (Picard, 1981, p. 116). Bou define el diario como 
una crónica cotidiana, escrita desde el presente, de una experiencia personal [...], quien escribe un diario se interesa por anotar los hechos de cada día, personales, familiares, literarios, político-sociales. Necesita el diario de unas mínimas condiciones: anotaciones periódicas, atención hacia lo inmediato, entidad literaria. Se caracteriza por la monotonía, la repetición de días, con sus gestos y acciones [...]. Tres elementos son fundamentales: el narrador escribe en primera persona, acerca de sí mismo; escribe sobre la realidad diaria, con un dominio claro del presente en que se produce la escritura, sin acceso al futuro; produce un informe escrito que, eventualmente, decide publicar (1996, pp. 124-125).

El devenir del diario desde su nacimiento en el siglo XVII hasta la actualidad -es a partir del XIX que conoce un verdadero desarrollo y es en el siglo XX, en el ámbito hispánico más concretamente a partir de la segunda mitad, cuando se produce una gran eclosión editorial (Freixas, 1996, pp. 5-9; Gallego Cuiñas, Estrade \& Idmhand, 2016, pp. 9-10)- ha determinado diversas fases que coinciden con modos y finalidades diarísticas distintas. En este sentido, Picard (1981, pp. 115 y ss.) marca tres momentos y tipos: diarios reales (o aliterarios ${ }^{5}$, marcados por la secreta intimidad con que el autor resguarda su texto y lo proyecta fuera del circuito comunicativo al vetar la posibilidad de cualquier otro lector que no sea el propio creador), diarios literarios (concebidos para la publicación desde el comienzo de la escritura) y diarios ficcionales (aquellos donde el yo es un personaje ficticio). Otra distinción importante es la que se establece entre diario externo o éxtimo y diario íntimo en función del grado de interioridad y cotidianeidad que aparezca en la obra (Gusdorf en Hierro, 1999, p. 114) ${ }^{6}$. Similar disparidad se establece entre las denominaciones de diario y dietario. Freixat parte de Girard para diferenciar el dietario respecto del anterior por el foco predominantemente intelectual, el carácter atemporal y la referencia a una intimidad del pensamiento alejada de lo propiamente vital (Freixas, 1996, p. 13).

\footnotetext{
${ }^{5}$ Picard defiende que el diario íntimo como tal es aliterario debido a que carece de la función comunicativa que posee la literatura. Por el contrario, en el momento en que se produce la impresión para su consumo por los lectores, la escritura diarística se convierte en género literario (1981, pp. 116, 117). Esta aliterariedad ha sido criticada por autores como Hierro (1999) o Luque Amo (2016).

${ }^{6}$ Dentro de un decálogo de características con las que define la realidad del diario, Gallego Cuiñas, Estrade e Idmhand aseguran que "es un género éxtimo" y se apoyan en Roland Barthes para negar el carácter íntimo de esta escritura puesto que "lo más interior de la subjetividad o es indecible, o en su defecto, al hacerse público se vuelve pura exterioridad o abstracción, se torna forma que se aleja de sí misma” (Gallego Cuiñas, Estrade \& Idmhand, 2016, p. 12).
} 
No obstante, las adjetivaciones de personal, íntimo o éxtimo difícilmente pueden entenderse desde la rigidez de límites inflexibles y, a menudo, son difuminadas por las anotaciones de los diarios que mezclan los elementos más eminentemente personales con las observaciones más externas. Por ello, para este estudio alcanza un mayor grado de operatividad la categorización en diario literario y no literario distinguida por Luque Amo. Este autor parte de la reconciliación que Pozuelo Yvancos establece entre las polaridades de la conocida oposición teórica entre Lejeune y De Man en torno a la autobiografía: respectivamente, la intención referencial del texto privilegiada por el autor de "El pacto autobiográfico" y la circunscripción textual y ficticia de la obra argumentada por el responsable de La autobiografía como desfiguración. Al aplicar esta confluencia de rasgos teóricos de la autobiografía al diario, Luque Amo subraya la afluencia de dos fundamentos para este último: el referencial y el ficticio. Desde esta perspectiva, especifica que los diarios literarios son aquellos que posibilitan la construcción mediante técnicas ficcionales de un sujeto que remite a un yo extratextual, mientras que caracteriza los diarios no literarios por un desarrollo que no permite erigir la figura del yo al limitarse a ofrecer documentación sin proyección narrativa ${ }^{7}$. En palabras de Luque Amo, el diario literario es

aquel texto que, escrito desde el presente y narrado en forma de crónica cotidiana, está protagonizado por un Yo que registra su día a día mediante entradas a veces fechadas y que, además, puede soportar una lectura literaria, en tanto que se construye con los mismos materiales de la ficción. Este texto está dirigido, pero no exclusivamente, al propio sujeto que lo escribe, el autor, que se desdobla en autor y receptor al mismo tiempo hasta que el texto se publica y el receptor pasa a ser universal (Luque Amo, 2016, pp. 297).

Al hablar del carácter literario de Rostros del reverso, del empleo de procedimientos narrativos en la elaboración del yo diarístico, toman relieve las estrechas coincidencias retóricas y temáticas que se establecen entre buena parte de su obra expresamente ficcional y aquella explícitamente au-

\footnotetext{
${ }^{7}$ Luque Amo asevera que los diarios no ficcionales "solo poseen un carácter documental [...] carecen de espacio textual para que el Yo se desarrolle y se autoconstruya"; es decir, se trata de "anotaciones [...] incapaces de soportar una lectura ficcional, de tal manera que de los dos estatutos que posee la escritura diarística [lectura referencial y lectura ficcional] solo podrían corresponderse con una lectura referencial del texto" (Luque Amo, 2016, pp. 291-292). En opinión de este crítico, "[e]l diario literario no es una clase [o] una modalidad de diario: no se opone al diario espiritual, al diario libertino o al diario político [...]. El diario literario es una categoría que solo se opone a la del diario como documento" (Luque Amo, 2016, p. 292).
} 
tobiográfica. García Vega ha afirmado la autorreferencialidad existente en los textos no autobiográficos a través de la inscripción del yo en una larga serie de heterónimos que habitan su escritura (como por ejemplo el doctor Fantasma o Tokol el Constructor de Cajitas) y que, como muestra Arcos, son todos representaciones de "un mismo personaje: el propio García Vega" (Arcos, 2012, p. 219) ${ }^{8}$. Entre las rendijas de los procedimientos metaliterarios e intertextuales que sustancialmente nutren Rostros del reverso (y sus otros textos autobiográficos), el proceso de construcción -deconstruccióndel yo es evidente en las anotaciones que recogen el anhelo, la angustia y la desesperanza del exiliado. No obstante, esta textualización del sujeto diarístico se realiza desde la conciencia de una conflictividad irresoluble que aquí se expresa a través del ansia por alcanzar su reverso y, en obras posteriores, en el símbolo del laberinto.

Los Rostros del reverso: diario del exilio

Dentro de la -hasta ahora- escasa publicación de diarios cubanos, la posición de Rostros del reverso es singular puesto que el volumen es editado en vida del autor. Frente a esta circunstancia, los escritos diarísticos de José Martí, José María Chacón y Calvo, Ernesto Che Guevara, José Lezama Lima y Alejo Carpentier son publicados tras la muerte de sus protagonistas. Puede considerarse que García Vega registra su cotidianeidad con vistas a la edición desde el principio, puesto que la sección del libro correspondiente a 1952, primer periodo datado, es publicada en el número 31 de la revista habanera Orígenes el mismo año de su escritura (Rojas, 2016, p. 91). El resto aparece en 1977, aproximadamente dos años después del último lapso recogido en las entradas de la obra: noviembre de 1975. De este modo, se concibe como un diario literario destinado a la publicación.

\footnotetext{
${ }^{8}$ Los heterónimos pueden ponerse en relación con sus juegos de estereotipias: rituales trascendidos desde la infancia y la juventud a la edad adulta que le permiten crear personajes con los que enfrentarse a la realidad. Esta ritualidad se encuentra muy relacionada con su autodeclarada neurosis o autismo que le impide formar parte del entorno o de lo grupal (Arcos, 2012, pp. 218219; Pintado en Aguilera, 2016, p. 36). Como argumenta Freud, "los actos ceremoniales y obsesivos nacen [...] como protección” (Freud, 1983, p. 1341). La incapacidad para participar en la realidad de García Vega, relegado a la condición de notario o de testigo, es denominada por Arcos como oblomovismo en alusión a las similitudes que establece con el personaje de Oblomov (1859), de Iván Goncharov y la película Unos días en la vida de Oblomov (1980), de Nikita Mikhalkov, basada en esta novela rusa del siglo XIX (Arcos, 2012, pp. 194, 197, 203).
} 
Coincide, sin embargo, García Vega en "la condición transmigráfica" que Mesa Gancedo ha descrito para el conjunto del género en la isla: "la historia de la escritura diarística en Cuba, una escritura siempre desplazada, encuentra en el nexo entre intimidad y conflicto una dialéctica singular" $\left(2013\right.$, p. 1557) ${ }^{9}$. De este modo, la traslación geográfica motivada por el trance nacional o personal actúa como motor recurrente de la escritura autorreflexiva y cotidiana entre los diaristas cubanos ${ }^{10}$. Como indica Mesa Gancedo, esta circunstancia es clave en la "serie de huellas fechadas" (Lejeune, 2012, p. 86) que García Vega deja tanto de los días aún vividos en su país como de los días del exilio. La salida desde su Jagüey Grande natal, en la provincia de Matanzas, hacia Cuba supone un sentimiento de exclusión que llega a alcanzar la neurosis. La salvación que del vivir enajenado le ofrece la actividad literaria y el vínculo con el grupo Orígenes es precaria. El autor siempre percibe su pertenencia a este colectivo desde la marginalidad. Las anotaciones recogidas a partir de 1968, tiempo de la salida de la isla y de la llegada a Madrid, indagan en la hondura de un extrañamiento que lo separa de las izquierdas europeas simpatizantes de la Revolución y de la comunidad de exiliados cubanos. Como dice Mesa Gancedo, en estos años los "propios conflictos personales [del exiliado García Vega] encuentran un profundo anclaje histórico" (Mesa Gancedo, 2013, p. 1555).

El diario abarca el periodo entre 1952 y 1975, que incluye los años vividos en Cuba durante la dictadura batistiana y el inicio de la Revolución, así como los años pasados en el exilio en Madrid y en Nueva York. No obstante, las entradas son irregulares y los periodos sin anotaciones llegan a corresponderse con años completos. Esta circunstancia, según Georges May, es recurrente en "la mayor parte de los diarios íntimos", donde "la cláusula de la anotación diaria no se cumple, y la escritura del diario a veces queda interrumpida por intervalos de tiempo más o menos largos" (cit. en Hierro, 1999, p. 115). García Vega comenta que el diario comienza específicamente con la "partida de Cuba, en el aeropuerto", el lunes 28 de octubre de 1968, aunque la primera anotación de ese año se corresponde con el lunes siguiente: el día 4 de noviembre (García Vega, 1977, p. 49). No obstante, el

\footnotetext{
${ }^{9}$ Mesa Gancedo identifica este concepto de transmigrafía con el de escritura nómada establecido por Fernando Aínsa en Palabras nómadas. Nueva cartografía de la pertenencia (2012).

${ }^{10}$ En su estudio Mesa Gancedo se ocupa de autores cubanos (Martí, Che Guevara, Chacón y Calvo, el propio García Vega) y de los diarios escritos por Pedro Henríquez Ureña y la española Zenobia Campubrí sobre el tiempo transcurrido en Cuba. Incluye además referencias a los diarios de ficción de Wendy Guerra. También pueden considerarse desde esta perspectiva los diarios de Venezuela de Alejo Carpentier, que aparecen bajo el título Diario (1951-1957) (La Habana, 2013).
} 
autor inserta dos capítulos anteriores dedicados a los años 1952 y 1957. Estos dos primeros periodos que abren Rostros del reverso incluyen alusiones a la experiencia espiritual y onírica del escritor. En ellos, las referencias a lo anecdótico público o privado son prácticamente inexistentes. Las reflexiones sobre los sueños y las teorizaciones sobre la escritura apenas dejan breves espacios a la mención de Cuba. Sin embargo, como afirma Rojas, se aprecia con claridad el rechazo a la situación de la cultura y la política del país, que en aquel entonces celebra el cincuenta aniversario de su nacimiento como República. Ya entonces, en las anotaciones de 1952, García Vega manifiesta "la falta de destino que implica escribir en Cuba" (Rojas, 2016, p. 78). Esta carencia le lleva a concebir el oficio de escritor como "oficio de perder": es decir, como autor condenado a no ser leído.

La circunstancia madrileña se construye fragmentariamente desde alusiones dispersas que componen el marco de la escritura. El autor describe esta época como tiempo de "días sumergidos" en los que reside, primero, en un hostal de la calle Princesa y, más adelante, en el Colegio Mayor Hispanoamericano Virgen de Guadalupe. Son “días de parálisis" y precariedad económica en los que permanece "acostado casi todo el día" (García Vega, 1977, p. 124) y vivir en Madrid se reduce a esperar el visado para viajar a Nueva York. Tan solo la rutina de los paseos por el parque de La Rosaleda en El Retiro, los museos, el cine, el aprendizaje del inglés como un esfuerzo penoso e inútil:

Salgo por la mañana a un parque, para esperar a que arreglen mi habitación. Son horas interminables las que paso allí, por lo que sólo tengo como variación el ir cambiando de bancos, según me sienta cansado de estar en un mismo sitio y el ir sacando el reloj, cada cuarto de hora, para ver cuánto me falta por esperar. Después [...] me paso el resto del día en mi habitación, mirando para las paredes. [...] No tengo con quién hablar. [...] // ¡A buen nivel de cero he llegado! (García Vega, 1977, p. 125).

El último periodo recogido en el diario son los años comprendidos entre 1972 y 1975, en los que el autor vive en Nueva York. Como en sus apuntes sobre Madrid, lo anecdótico narrado de modo esquemático aparece disperso bajo el predominio de fragmentos metaliterarios sin que por ello el yo deje de construirse como personaje del relato. En las entradas correspondientes a las fechas de la etapa neoyorquina, García Vega revela una cotidianeidad aplastante bajo el peso enfermizo de sus obsesiones neuróticas. En la ciudad estadounidense vive en una buhardilla y la esterilidad de los días se traduce en la jornada de ocho horas diarias de oficina, que 
alterna con la rutina en el hogar ya reunido con su esposa Marta, las sesiones de psicoanálisis, la hora dedicada (de modo frustrante y casi heroico) al aprendizaje de idiomas escuchando discos de inglés, los viernes de güisqui escocés y los domingos de comida-cubana, los cines, los museos y el tiempo con algunos amigos como Víctor Batista o Carlos M.

Rostros del reverso explícitamente trata sin lograrlo de no ser el "diario de un enfermo" (García Vega, 1977, p. 85). En esta obra el desajuste perceptivo y sensitivo, que el propio autor achaca a la neurosis que le afecta, encuentra un cauce adecuado en el molde genérico del diario, que Lejeune caracteriza por "la inconsistencia y la repetición estereotipada" (Lejeune, 2009, p. 151; mi traducción). De este modo, los rasgos del género -fragmentarismo, personalismo y libertad formal- se dan la mano con las singularidades del autor: por un lado, la imposibilidad de alcanzar una normalidad sensorial $y$, por otro, la apuesta por un modelo de escritura fundamentalmente no anecdótico y de objetiva geometría imaginística afín a la expresión cubis$\mathrm{ta}^{11}$. El reverso aludido desde el título se manifiesta en múltiples facetas: la política, el exilio, la vida, la escritura:

Y comienza el diario... ¿Rostros del reverso? ¿De nuevo aquel reverso? Aquel que perseguí, casi, en mi adolescencia. No sé... Pero puedo encontrar analogía entre esta nueva situación, y esos puntos oscuros, esos equívocos, que siempre me obsesionaron. ¡Ah de un paisaje! He dudado del paisaje. Dudo de mi paisaje. // El reverso, paisaje, país, y este diario que ahora comienzo: exilio..., ¿exilio? Reverso: buscaba, busqué siempre, en la poesía, ese punto, esa irradiación, donde una imagen, una impresión, un roce de lo maravilloso, me ofrecían, de inmediato, junto a lo hiriente de su belleza, el reto como de su estructura, de su revés, de sus orígenes. Paisaje: situarlo -eso me obsesionaba- en lo seco de sus últimos elementos, en una como ascesis cubista. País: y esto de la búsqueda de un posible de nuestro paisaje -esto también me obsesionaba- como lo pobre, como lo escaso, como el sumergirnos, desesperadamente, en lo único que nos quedaba. // El lunes pasado comienza este diario. Allí fue la partida de Cuba, en el aeropuerto. // [...] Pero no puedo... pero no quiero hablar (García Vega, 1977, p. 49).

El sustantivo reverso del título aplicado al propio García Vega alude a su posición de contraescritor o, como él se define, de escritor-no escritor, que

${ }^{11}$ Las afinidades con el vanguardismo de la obra de García Vega son evidentes, especialmente respecto del cubismo. Según Lezama, los rasgos de este ismo son ya predominantes en el primer poemario Suite para la espera (1942), de García Vega. 
determina la conciencia de la literatura como un oficio de perder. También apunta a la relación con su pasado origenista que hace de la crítica contenida en Los años de orígenes un contrahomenaje a la figura de Lezama, su maestro, que inventó para él -nos cuenta- el curso délfico, iniciado con la frase trampolín: "Muchacho, lee a Proust" (en Aguilera, 2016, p. 163) 12. $^{2}$. Igualmente, alude a la conciencia de exiliado cubano como envés de otros expatriados políticos hispanoamericanos, incluso de otros exiliados cubanos:

Se trata de lo que yo experimenté, en 1968, al salir de mi país para no regresar más. // [...] Me encontré, entonces (estoy hablando, adviertan, de la sabrosa década del sesenta), con que casi todo el mundo presumía de pertenecer a una rara categoría de exiliados, pero que ellos no sólo estaban con muy buenas becas, seguían comprándose los mejores zapatos, y seguían teniendo relaciones con su país, sino que, al cumplirse un tiempo más o menos corto, volverían a entrar en la patria y a otra cosa. // Me encontré, entonces, cosa más rara todavía, que al salir yo de una Isla privilegiada por la propaganda juvenil, idealista, tercermundista, o lo que carajo fuera, yo no era un exiliado ni mucho menos, ya que yo sólo era un tarado que por gusto se había vuelto apátrida. // [...] Esto... Pero, ipara, para cochero! [...]. Perdonen, respetable público, perdonen. Se me fue la mano y me he puesto a hablar de un exilio, o de un noexilio, del que no se puede hablar (en Aguilera, 2016, p. 161).

El reverso es narración iterativa, elíptica y giratoria, fuertemente metadiscursiva e intertextual, poseída por la expresión de un persistente sentimiento de duda y marginalidad proveniente de una confesada neurosis personal y del contexto histórico, el gusto por las expresiones y palabras coloquiales que socavan el lenguaje académico y por un permanente, aunque amargo, sentido del humor. La idea de reverso condiciona una escritura que, coincidiendo con la visión del diario como taller de escritura del autor, constantemente se vuelve relato de "un intento de narrar" e inven-

${ }^{12}$ Este negativo fotográfico de Lezama toma forma nuevamente en "Maestro por penúltima vez", conferencia leída por García Vega en Madrid en 2009, donde vuelve a hacer explícita la ambivalente tensión entre su figura y la de su mentor. Así, narra el "encuentro con un Maestro endemoniado en un ambiente frío, áspero, como fue la Cuba de mi juventud. Un encuentro y una entrada en un grupo literario que, por supuesto, no disolvió mi desequilibrio, pero que sí me ofreció la tabla de salvación de la literatura (o sea, tuve una alternativa: o volverme un literato, o vivir como un enfermo inútil). O sea, que logré, a través del aprendizaje que me ofreció un Maestro (un aprendizaje que comenzó cuando me prestó el primer libro de lo que fue su curso, que duró dos años: Los cantos de Maldoror" (en Aguilera, 2016, p. 163). 
tario de "piezas fragmentarias" (García Vega, 1977, p. 220). En las páginas finales este cauce expresivo se extrema al ofrecer el boceto de una novela del exilio -donde el objeto de reflexión fundamental lo ocupa la creación del verdadero paisaje cubano, tras la estela de los poetas exiliados del XIX y cuya esencialidad se enfrenta al escenario sin color de Playa Albina (Miami) - realizada por un "joven esquizofrénico", heterónimo de García Vega, al que llama Calixto Abad: “¿tuvimos los cubanos un paisaje? [sic] ¿No nos movimos siempre, en la imagen, como si fuéramos extranjeros? Habría que indagar en lo de nuestro paisaje inventado, en lo que nuestros exiliados del siglo pasado soñaron y superpusieron a una circunstancia sin rostro?" (García Vega, 1977, p. 201) ${ }^{13}$.

\section{CONCLUSIÓN}

A través de Rostros del reverso, García Vega inicia una relación explícita con la escritura autobiográfica que se prolonga en textos sucesivos hasta el final de su vida. La afinidad con una práctica diaria que supone "el reverso íntimo de la escritura" (Gallego Cuiñas et al., 2016, p. 10) ha sido ampliamente confesada por el autor y ha dado lugar a una de las obras más profusas y singulares del género en Cuba. Frente a otras formas simplemente documentales, Rostros del reverso es un diario literario: si por un lado, está destinado desde el comienzo de su redacción a ser publicado; por otro, la abundante presencia de lo metaliterario en sus páginas no cancela el desarrollo narrativo del yo, de forma que se construye sobre un fundamento referencial y otro ficcional, las dos bases definidoras de esta modalidad. El trauma del desplazamiento, que el escritor comparte con otros diaristas coterráneos, por motivos históricos e individuales se configura como motor de las anotaciones cotidianas desde un angustioso presente sufrido por García Vega tanto en el extrañamiento y margen de la vida cubana como en el exilio español y estadounidense. La pulsión diarística y, en la singular expresión del autor, el placer de morderse las uñas del yo se convierten en cauces predilectos de la escritura, de manera que los principales rasgos de

${ }^{13}$ El final de Rostros del reverso avanza en esquema el plan de la obra: estructura, tema y estilo. La novela anunciada se puede asociar fácilmente con El oficio de perder y está indirecta, pero expresamente, vinculada a la novelística de Robbe-Grillet, teorizador de la nueva novela durante fines de los años cincuenta y los sesenta. Por otra parte, respecto de la función del diario como taller literario, Jordi Gracia menciona la "forma abierta" del género que tiene "mucho de laboratorio de ideas literarias y de ejercicio en acto de esas ideas” (cit. en Luque Amo, 2016, p. 293). 
esta modalidad coinciden frecuentemente en el estilo con que se interna en otras formas literarias a lo largo de su producción posterior.

\section{REFERENCIAS}

Aguilera, C. A. (2016). La Patria Albina: exilio, escritura y conversación en Lorenzo García Vega. Leiden: Almenara.

Arcos, J. L. (03 de junio de 2008). "Me he acostumbrado a ser un apátrida" [Entrevista con Lorenzo García Vega]. Cubaencuentro. Recuperado de http:// www.cubaencuentro.com/entrevistas/articulos/me-he-acostumbrado-aser-un-apatrida-88514

. (2012). Kaleidoscopio: la poética de Lorenzo García Vega. Madrid: Colibrí.

Blanchot, M. (2002). El espacio literario. Madrid: Editora Nacional.

Bou, E. (1996). "El diario: periferia y literatura". Revista de Occidente, 182-183, 121-135.

Cuba Soria, P. de (2016). "Confesiones del reverso". En C. A. Aguilera (Ed.), La patria albina. Exilio, escritura y conversación en Lorenzo García Vega (pp. 109-117). Leiden: Almenara.

Espinosa Domínguez, C. (2016). "Me dirijo a un lector que todavía no existe". En C. A. Aguilera (Ed.), La patria albina. Exilio, escritura y conversación en Lorenzo García Vega (pp. 95-108). Leiden: Almenara.

Franco, S. R. (2012). In(ter)venciones del yo. Escritura y sujeto autobiográfico en la literatura hispanoamericana (1974-2002). Madrid; Frankfurt: Iberoamericana; Vervuert.

Freixas, L. (1996). “Auge del diario ¿íntimo? en España”. Revista de Occidente, 182-183, 5-14.

Freud, S. (1983). Los actos obsesivos y las prácticas religiosas. En S. Freud, Obras completas (pp. 1337-1342). Vol. 4. Madrid: Editorial Nueva.

Gallego Cuiñas, A., Estrade, C., \& Idmhand, F. (Eds.) (2016). Diarios latinoamericanos del siglo XX. Bruxelles, et al.: Peter Lang.

García Vega, L. (1977). Rostros del reverso. Caracas: Monte Ávila. . (1978). Los años de Orígenes. Caracas: Monte Ávila. . (2005a). El oficio de perder. Sevilla: Renacimiento.

. (2005b). No mueras sin laberinto: poemas 1998-2004. Buenos Aires: Bajo la luna.

. (2011). La pata sobre el huevo. Recuperado de http://lapatasobrelhuevo. blogspot.com.es/

Hierro, M. (1999). "La comunicación callada de la literatura: reflexión teórica sobre el diario íntimo". Mediátika, 7, 103-127.

Lejeune, P. (2009). On Diary. Popkin, J. D. y Rak, J. (Eds.) Honolulu: Biographical Research Center; University of Hawaii Press. 
. (2012). "De la autobiografía al diario: historia de una deriva". Rilce: Revista de Filología Hispánica, 28(1), 82-88.

Luque Amo, A. (2016). El diario personal en la literatura: Teoría del diario literario. Castilla. Estudios de Literatura, 7, 273-306.

Mesa Gancedo, D. (2013). “Transmigrafía, intimidad y conflicto en la escritura diarística cubana del siglo XX”. En C. Reverte Bernal (Ed.), Diálogos culturales en la literatura iberoamericana (pp. 1544-1558). Madrid: Verbum.

. (2014). "Diario y autoficción en la narrativa hispanoamericana contemporánea”. En A. Casas (Ed.), El yo fabulado: Nuevas aproximaciones críticas a la autoficción (pp. 191-206). Madrid; Frankfurt: Iberoamericana; Vervuert.

Picard, H. R. (1981). "El diario como género entre lo íntimo y lo público”. 1616. Anuario de la Sociedad Española de Literatura General y Comparada, 4, 115122.

Pintado, M. (2016). "Metafísica de un escritor-no escritor”. En C. A. Aguilera (Ed.), La patria albina. Exilio, escritura y conversación en Lorenzo García Vega (pp. 33-41). Leiden: Almenara.

Rojas, R. (2016). “Formas de lo siniestro cubano”. En C. A. Aguilera (Ed.), La patria albina. Exilio, escritura y conversación en Lorenzo García Vega (pp. 71-92). Leiden: Almenara.

Rudd, A. (2011). "Following Where the Brush Leads: The Potential of the Zuihitsu in American Postmodernist Literature”. Plaza: Dialogues in Language and Literature 1 (1), 42-49.

Toro, A. de (2007). "Meta-autobiografíalAutobiografía transversal postmoderna o la imposibilidad de una historia en primera persona”. Estudios Públicos, 107, 213-308. 